\title{
INOVASI JAMINAN KESEHATAN SEMESTA DALAM USAHA MENINGKATKAN KUALITAS PELAYANAN KESEHATAN BAGI PESERTA JAMINAN PENYANGGA DI DAERAH ISTIMEWA YOGYAKARTA
}

\author{
Nova Lestari ${ }^{1}$ dan Yanuardi ${ }^{2}$
}

\begin{abstract}
This research aims to know and understand about the implementation of the innovation of Universal Health Insurance (Jamkesta) system in an effort to improve health care quality for participants buffer in Yogyakarta. This reseach used descriptive qualitative method. Data collected by interview and observation. Data validity checking is done through a method of triangulation. The process of data analysis include data reduction, data presentation, and conclusion. The results showed that the element of human resources, processes, financing, location, response to suggestions for improvements innovation, law, and social supports the implementation of Universal Health Insurance for participant buffer and newborns. However, there are still some deficiencies that need to be corrected when viewed from the elements of socialization, culture and technology. Meanwhile, elements of the results showed that as many as $45 \%$ of the total number of participants for eligibility letter (SEP) printed out by Bapel Jamkesos is for the class buffer without ID cards and newborns. This indicates that the Jamkesta vision and mandate of the Governor of Yogyakarta has been reached.
\end{abstract}

Keywords: Innovation, Universal Health Insurance, and Health Care.

\begin{abstract}
ABSTRAK
Penelitian ini bertujuan untuk mengetahui dan memahami tentang pelaksanaan inovasi sistem Jaminan Kesehatan Semesta (Jamkesta) dalam usaha meningkatkan kualitas pelayanan kesehatan peserta jaminan penyangga di Daerah Istimewa Yogyakarta. Penelitian ini menggunakan metode deskriptif kualitatif. Teknik pengumpulan data dilakukan dengan cara wawancara dan observasi. Pemeriksaan keabsahan data dilakukan melalui metode triangulasi sumber. Proses analisis data mencakup reduksi data, penyajian data, dan penarikan kesimpulan. Hasil penelitian menunjukkan bahwa unsur SDM, proses, pembiayaan, lokasi, respon terhadap saran perbaikan inovasi, hukum, dan sosial sudah mendukung pelaksanaan inovasi Jaminan Kesehatan Semesta terhadap golongan penyangga dan bayi baru lahir. Namun, masih terdapat beberapa kekurangan yang perlu diperbaiki jika dilihat dari unsur sosialisasi, budaya dan teknologi. Sementara itu, unsur hasil menunjukkan bahwa sebanyak $45 \%$ dari total jumlah surat eligibilitas peserta (SEP) yang dikeluarkan oleh Bapel Jamkesos adalah untuk golongan penyangga tanpa KTP dan bayi baru lahir. Hal tersebut mengindikasikan bahwa visi Jamkesta dan amanah dari Gubernur DIY sudah tercapai.
\end{abstract}

Kata kunci: Inovasi, Jaminan Kesehatan Semesta, dan Pelayanan Kesehatan.

1,2 Jurusan Ilmu Administrasi Negara, Fakultas Ilmu Sosial, Universitas Negeri Yogyakarta 


\section{PENDAHULUAN}

Pada tahun 2011, BPJS telah dibentuk berdasarkan Undang-undang Nomor 24 tahun 2011, dan diperkuat dengan Peraturan Menteri Kesehatan Republik Indonesia Nomor 28 tahun 2014 tentang Pedoman Pelaksanaan Program Jaminan Kesehatan Nasional. Program yang juga dikenali sebagai Jaminan Kesehatan Nasional (JKN) ini secara resmi mulai diimplementasikan sejak 1 Januari 2014. Dalam kebijakan JKN, terdapat kekurangan jika dilihat dari persyaratan pertama dan kedua, yakni peserta perlu memiliki KTP dan KK. Apabila calon peserta tidak dapat memenuhi persyaratan yang diperlukan, secara otomatis permohonan keanggotaan JKN tidak dapat diproses. Selain masalah administrasi, BPJS juga menghadapi masalah yang lain dari segi cakupan keanggotaan BPJS yang tidak merata dan dinilai tidak adil. Warga masyarakat dengan tingkat ekonomi menengah keatas ikut menjadi anggota, yang pada akhirnya menyebabkan golongan masyarakat dengan tingkat ekonomi menengah kebawah terabaikan. Hal ini disebabkan oleh manipulasi data dan ketidaktelitian dalam proses pendataan.

Untuk mengatasi permasalahan tersebut, pemerintah daerah Daerah Istimewa Yogyakarta telah memperkenalkan sistem Jaminan
Kesehatan Semesta (Jamkesta). Sistem ini diperkuat dengan adanya peraturan gubernur Daerah Istimewa Yogyakarta nomor 63 tahun 2016 tentang sistem Jaminan Kesehatan Semesta. Jika ditinjau dari pelaksanaannya, inovasi dari sistem Jamkesta adalah pemberian jaminan kesehatan untuk golongan masyarakat yang tidak memiliki identitas resmi berupa KTP dan KK. Mereka dapat memperoleh bantuan dari rumah sakit yang bekerja sama dengan Jamkesta, dengan catatan bahwa golongan masyarakat tersebut tinggal di DIY saat mengajukan permohonan dan sudah mendapatkan rekomendasi dari dinas terkait.

Golongan penyangga yang dimaksud adalah gelandangan, pengemis, pemulung, dan anak jalanan, atau yang lebih dikenali sebagai penyandang masalah kesejahteraan sosial (PMKS) serta bayi baru lahir yang orang tuanya bukan merupakan anggota PBI JKN. Urgensi penelitian ini didasarkan pada jumlah PMKS yang ada di Daerah Istimewa Yogyakarta pada tahun 2014 yang berjumlah 669 orang. (Laporan Hasil Pemutakhiran Data PMKS dan PSKS Tahun 2014) Jumlah tersebut tentunya tidak tetap, karena masih banyak golongan PMKS yang memilih untuk hidup bebas di lingkungan masyarakat tanpa terikat 
dengan lembaga apa pun. Sementara itu, angka lahir hidup pada tahun 2014 di DIY adalah 54.773 jiwa (Kemenkes RI, 2014). Data menunjukkan bahwa Jamkesta memang sangat diperlukan untuk menjamin kesehatan golongan-golongan tersebut karena sila kelima dari pancasila menyatakan secara tersirat bahwa setiap rakyat indonesia memiliki hak yang sama dalam memperoleh pelayanan dari pemerintah. Oleh karena itu, peneliti tertarik untuk melakukan penelitian tentang proses pelaksanaan "Inovasi Jaminan Kesehatan Semesta dalam Usaha Meningkatkan Kualitas Pelayanan Kesehatan bagi Peserta Jaminan Penyangga di Daerah Istimewa Yogyakarta".

Kajian teori yang digunakan di dalam penelitian ini adalah kebijakan publik, pelayanan publik, pelayanan kesehatan, inovasi, dan kesehatan. Teori inovasi yang digunakan dalam penelitian ini berasal dari Imanuddin (2015:298), yang mengemukakan inovasi pelayanan publik dapat dipahami sebagai inisiatif terobosan dari instansi/lembaga publik dalam upaya meningkatkan kualitas pelayanan publik. Inisiatif terobosan tersebut terletak pada kebaruan (novelty). Prinsip kebaruan tersebut dibedakan dengan inovasi dalam teknologi yang merupakan keunikan yang khas berbeda dengan yang lain. Kebaruan boleh merupakan pengembangan dari inovasi pelayanan publik yang telah ada, karena inovasi pelayanan publik terus diperbaharui dan bahkan ditiru dengan cara melakukan replikasi. Dengan bahasa populer replikasi inovasi pelayanan publik dilakukan dengan proses yang mudah yaitu Amati, Tiru, dan Modifikasi atau disingkat dengan ATM.

Adapun unsur-unsur yang digunakan untuk memudahkan proses reduksi data dan analisis data diperoleh dari disertasi Imanuddin (2015). Poin pembahasan terbagi kepada dua unsur utama, yakni unsur internal yang meliputi sumberdaya manusia, proses, hasil, pembiayaan, lokasi, sosialisasi, dan Respon terhadap saran perbaikan inovasi. Unsur kedua adalah unsur eksternal, yang terdiri daripada hukum, budaya, teknologi, dan sosial.

Tujuan penelitian ini adalah untuk mengetahui, memahami, serta memberi masukan kepada aktor-aktor pelaksana guna mengoptimalkan pelaksanaan inovasi sistem Jaminan Kesehatan Semesta yang didasarkan pada Peraturan Gubernur DIY Nomor 63 Tahun 2016 tentang Jaminan Kesehatan Semesta dalam usaha meningkatkan kualitas pelayanan kesehatan peserta jaminan penyangga di Daerah Istimewa Yogyakarta. 


\section{METODE}

Penelitian ini menggunakan pendekatan deskriptif dengan pendekatan kualitatif. Penelitian ini mengambil tempat di Daerah Istimewa Yogyakarta dan dilakukan dari bulan Oktober 2016 hingga bulan Desember 2016. Peneliti menentukan pihak-pihak tersebut sebagai subjek penelitian karena mereka adalah pihak yang terlibat secara langsung dalam pelaksanaan sistem ini, sehingga peneliti meyakini bahwa pihak-pihak tersebut memiliki pengetahuan yang luas dan mampu menjelaskan pelaksanaan sistem Jamkesta untuk golongan penyangga dan bayi baru lahir dengan baik dan jelas.

Untuk mengecek keabsahan data, peneliti menggunakan teknik pemeriksaan triangulasi sumber. Peneliti melakukan triangulasi sumber dengan cara membandingkan pendapat dari tiga informan berbeda, yakni dari Dinas Kesehatan DIY, Bapel Jamkesos, dan Dinas Sosial DIY. Kemudian data-data yang ada dibandingkan pula dengan hasil observasi di lapangan. Setelah data di lapangan dinilai sudah valid, peneliti membandingkannya lagi dengan dokumendokumen pendukung.

Teknik analisis data yang digunakan dalam penelitian ini menggunakan teknik analisis data model interaktif Miles dan Huberman (Sugiyono, 2011) yang meliputi reduksi data, penyajian data, dan penarikan kesimpulan.

\section{HASIL DAN PEMBAHASAN}

Inovasi yang terdapat di dalam sistemJaminan Kesehatan Semesta (Jamkesta) adalah pemberian jaminan kesehatan untuk PMKS tanpa KTP dan bayi baru lahir yang orang tuanya bukan merupakan anggota resmi PBI JKN. Dalam penelitian ini, peneliti menggunakan unsur yang dikemukakan oleh Imanuddin (2015) untuk mencari data dan menganalisis data. Unsur pelaksanaan inovasi pelayanan publik terbagi kepada dua, yakni unsur internal dan unsur eksternal.

\section{Unsur Internal Inovasi Pelayanan Publik}

\section{Sumber Daya Manusia}

Satuan kerja perangkat daerah (SKPD) yang terlibat secara langsung dalam pelaksanaan inovasi Jamkesta untuk golongan penyangga dan bayi baru lahir meliputi Dinas Sosial DIY (Dinsos DIY), Dinas Kesehatan DIY (Dinkes DIY), dan Badan Pelaksana Jaminan Kesejahteraan Sosial (Bapel Jamkesos). Setiap SKPD tersebut memiliki tugas dan kontribusi dalam mendukung keberhasilan pelaksanaan sistem ini. Tabel dibawah menunjukkan 
ciri-ciri dan fungsi dari SKPD-SKPD tersebut.

Tabel 1. SDM SKPD pelaksana Jamkesta

\begin{tabular}{|c|c|c|c|}
\hline $\begin{array}{l}\text { SKPD } \\
\text { Poin }\end{array}$ & $\begin{array}{l}\text { Dinsos } \\
\text { DIY }\end{array}$ & $\begin{array}{l}\text { Dinkes } \\
\text { DIY }\end{array}$ & $\begin{array}{l}\text { Bapel } \\
\text { Jamkesos }\end{array}$ \\
\hline $\begin{array}{l}\text { Pelaksa } \\
\text { na }\end{array}$ & $\begin{array}{l}\text { Bagian } \\
\text { data, } \\
\text { Subag } \\
\text { Program } \\
\text { dan } \\
\text { Informasi }\end{array}$ & $\begin{array}{l}\text { Seksi } \\
\text { Pembiayaa } \\
\text { n dan } \\
\text { Jaminan } \\
\text { Kesehatan } \\
\text { (PJK) }\end{array}$ & $\begin{array}{l}\text { Seksi } \\
\text { Pemelihar } \\
\text { aan } \\
\text { Kesehatan } \\
\text { (Harkes) } \\
\text { dan Tata } \\
\text { Usaha } \\
\text { (TU) }\end{array}$ \\
\hline Peran & $\begin{array}{l}\text { Koordinat } \\
\text { or proses } \\
\text { verifikasi } \\
\text { dengan } \\
\text { Dinsos } \\
\text { Kabupate } \\
\text { n/Kota } \\
\text { dan } \\
\text { validasi } \\
\text { data }\end{array}$ & $\begin{array}{l}\text { verifikasi } \\
\text { administra } \\
\text { ti, } \\
\text { mediator, } \\
\text { dan } \\
\text { regulator }\end{array}$ & $\begin{array}{l}\text { Penerbitan } \\
\text { SEP dan } \\
\text { penanggun } \\
\text { gjawab } \\
\text { dana } \\
\text { Jamkesta }\end{array}$ \\
\hline $\begin{array}{l}\text { Jumlah } \\
\text { Pegawa } \\
\text { i }\end{array}$ & $\begin{array}{l}\text { Menurut } \\
\text { SK: dua } \\
\text { orang } \\
\text { (verifikasi } \\
\text { di } \\
\text { lapangan) }\end{array}$ & $\begin{array}{l}\text { Tujuh } \\
\text { orang }\end{array}$ & $\begin{array}{l}\text { Lima } \\
\text { orang }\end{array}$ \\
\hline $\begin{array}{l}\text { Kualifi } \\
\text { kasi } \\
\text { Pendidi } \\
\text { kan }\end{array}$ & $\begin{array}{l}\text { S1 Ilmu } \\
\text { Sosial }\end{array}$ & $\begin{array}{l}\text { S1 } \\
\text { Kesmas } \\
\text { atau yang } \\
\text { berkaitan }\end{array}$ & $\begin{array}{l}\text { Harkes: S1 } \\
\text { Kesmas } \\
\text { atau yang } \\
\text { berkaitan }\end{array}$ \\
\hline
\end{tabular}

Sumber: Penelitian Diolah (2017)

Pegawai-pegawai yang ada di SKPD pelaksana memiliki kredibilitas yang tinggi. Penilaian ini dibuat dengan memerhatikan aspek kesesuaian tingkat pendidikan pegawai-pegawai yang berada di instansi-instansi tersebut, kemampuan setiap pegawai untuk membuat laporan pada setiap akhir bulan melalui aplikasi monitoring dan evaluasi yang diawasi oleh BAPPEDA (diperkuat dengan adanya mekanisme reward and punishment), pembekalan khusus untuk setiap pegawai dengan jabatan fungsional umum (JFU) untuk memastikan bahwa mereka mampu menjalankan tugas sesuai dengan kapasitas yang ditentukan, dan pelaksanaan tugas sesuai dengan standar operasional prosedur (SOP). Dengan adanya SOP, alur kerja mereka akan menjadi lebih jelas dan pegawai-pegawai di SKPD kelompok teknis menjadi lebih disiplin dengan cara mengurangi potensi terjadinya korupsi waktu.

Dengan demikian, dapat disimpulkan bahwa pendidikan, monitoring dan evaluasi, pembekalan pegawai dan standar operasional prosedur (SOP) merupakan hal yang sangat menentukan kinerja pegawai pelaksana sistem Jamkesta. Hal-hal tersebut dapat meningkatkan kredibilitas pegawai, yang akhirnya mampu menjamin kepercayaan masyarakat terhadap kinerja SKPD pelaksana Jamkesta untuk golongan penyangga dan bayi baru lahir.

\section{Proses}

Proses pelaksanaan Jamkesta untuk golongan penyangga dan bayi baru lahir melibatkan Dinas Sosial DIY dan Dinas Sosial Kabupaten/Kota, Dinas Kesehatan DIY, dan Badan Pelaksana Jaminan Kesejahteraan Sosial (Bapel Jamkesos).

Golongan penyangga dan bayi baru lahir mampu mendapatkan bantuan ini karena Bapel Jamkesos menerbitkan Surat 
Eligibilitas Peserta (SEP). SEP berfungsi untuk memberikan kepastian kepada rumah sakit atau puskesmas bahhwa biaya perawatan pasien akan dibayarkan oleh pemerintah daerah DIY. Selain itu, prosedur pembiayaan Jamkesta dinilai jelas, sederhana dan pasti karena setiap SKPD kelompok teknis menjalankan tugasnya sesuai dengan SOP sehingga masyarakat tidak akan terbebani pembiayaan Jamkesta.

Proses pembiayaan Jamkesta untuk golongan penyangga dan bayi baru lahir dapat dilaksanakan dengan adanya surat eligibilitas peserta (SEP). Untuk memastikan kualitas pelayanan kesehatan, setiap SKPD pelaksana memiliki landasan kerja berupa standar operasional prosedur (SOP).

\section{Hasil}

Pelaksanaan inovasi sistem Jamkesta mampu menghasilkan pelayanan publik yang tepat sasaran, dengan cara melindungi hak-hak masyarakat yang sebelum ini luput dari perhatian pemerintah pusat, seperti gelandangan, pengemis, pemulung, dan anak jalanan. Berikut merupakan data yang diperoleh dari laporan pelaksanaan kegiatan Bapel Jamkesos tahun 2016:

Dari bulan Januari hingga bulan Oktober tahun 2016, jumlah SEP yang dikeluarkan untuk golongan PMKS (gelandangan, pengemis, pemulung dan anak jalanan) berjumlah 5262 lembar surat atau $21 \%$ dari jumlah SEP yang dikeluarkan oleh Bapel Jamkesos pada tahun 2016, yakni 25.577 lembar SEP. Sementara itu, jumlah SEP yang dikeluarkan untuk bayi baru lahir adalah sebanyak 6163 lembar surat atau $24 \%$ dari jumlah SEP yang dikeluarkan. Jika dilakukan penjumlahan, presentase penerima SEP untuk golongan PMKS tanpa KTP dan bayi baru lahir adalah $45 \%$. Data tersebut digambarkan dalam grafik sebagai berikut:

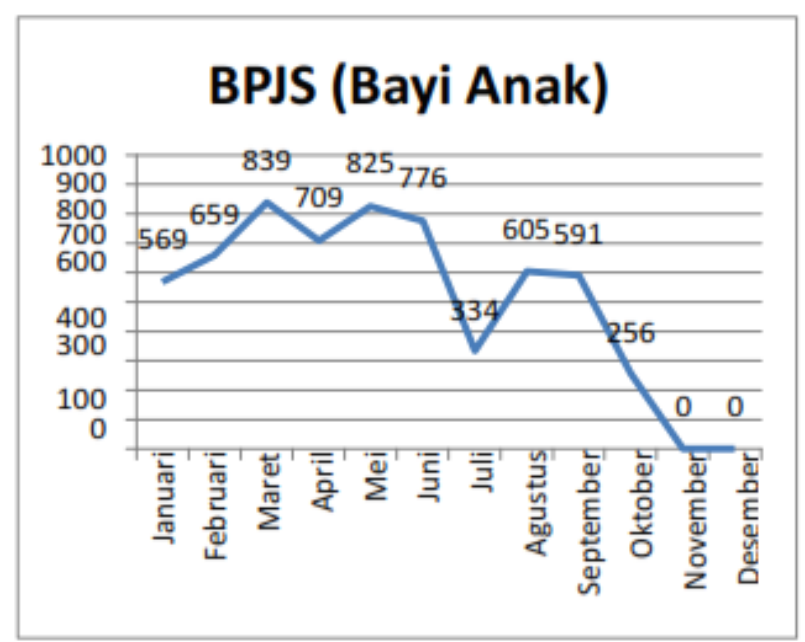

Sumber: laporan pelaksanaan kegiatan Jamkesta di Bapel Jamkesos tahun 2016

Grafik 1. Jumlah SEP yang dikeluarkan oleh Bapel Jamkesos kepada bayi baru lahir hingga Oktober 2016

Pelaksanaan tugas sesuai dengan SOP dapat memberikan kepastian waktu dalam proses pengurusan klaim. Proses verifikasi dan penerbitan surat rekomendasi yang dilakukan oleh Dinas Sosial, penerbitan surat rekomendasi dari 
Dinkes DIY, dan pengurusan Surat Eligibilitas Peserta (SEP) di Bapel Jamkesos memiliki batas-batas waktu tertentu, sehingga masyarakat akan merasa nyaman dan puas ketika mendapatkan pelayanan di instansi pemerintah.

Kesimpulannya, sistem ini mampu menghasilkan pelayanan publik yang berkualitas, yang diukur dari kepastian waktu pelayanan yang diberikan. Selain itu, sistem ini juga mampu memberikan pelayanan kesehatan kepada golongangolongan yang sebelum ini luput dari perhatian Jaminan Kesehatan Nasional $(\mathrm{JKN})$.

\section{Pembiayaan}

Pembiayaan Jaminan Kesehatan Semesta (Jamkesta) seratus persen bersumber dari Anggaran Pendapatan dan Belanja Daerah (APBD) DIY. Oleh karena itu, cakupan pembiayaan Jamkesta hanya terbatas untuk masyarakat yang menetap di Daerah Istimewa Yogyakarta pada saat pengajuan klaim bantuan Jamkesta. Pada tahun 2016, anggaran dari Pemerintah Daerah (Pemda) untuk pendanaan Jamkesta adalah $\mathrm{Rp}$ 67.000.000.000,00. Dana itu digunakan khusus untuk biaya operasional dan pembiayaan klaim Jamkesta.

Dari dana tersebut, $5 \%$ atau sekitar Rp.3.350.000.000,00 diperuntukkan untuk membiayai golongan buffer. Buffer adalah istilah yang dipakai untuk golongan Jamkes penyangga, yang meliputi golongan PMKS, miskin tanpa jaminan, disabilitas miskin tanpa jaminan, kader tanpa jaminan, dan rawan kesehatan. Apabila dana buffer tersebut kurang, maka Bapel Jamkesos akan mempergunakan dana pembiayaan umum untuk menutupi kekurangan tersebut. Dengan kata lain, dana pembiayaan bantuan Jamkesta sentiasa mencukupi. Sementara itu, proses pencairan dana bantuan Jamkesta yang begitu panjang mampu menghindari potensi terjadinya korupsi anggaran dikalangan SKPD pelaksana karena pegawai tidak memegang secara langsung uang tersebut dan Bapel Jamkesos diharuskan untuk membuat laporan keuangan setiap tiga bulan sekali kepada kas Pemda DIY. Dengan demikian, dapat dikatakan bahwa sistem pembiayaan Jamkesta sudah transparan.

Pembiayaan Jamkesta sudah efektif jika dilihat dari cakupan pembiayaan dan efisien jika dilihat serapan dana, yang mana anggaran dana setiap tahun yang diturunkan oleh kas Pemda DIY bersumber dari masukan Bapel Jamkesos, sehingga kualitas serapan dana dapat ditingkatkan dari tahun ke tahun. Dengan demikian, jumlah uang yang perlu dikembalikan ke 
kas daerah setiap akhir tahun dapat di minimalkan.

\section{Lokasi}

Cakupan pembiayaan Jamkesta meliputi empat Kabupaten dan satu kota di Daerah Istimewa Yogyakarta. Berdasarkan data yang diperoleh dari laporan pelaksanaan kegiatan Jamkesta di Bapel Jamkesos sepanjang tahun 2016, golongan penyangga yang menerima bantuan Jamkesta dengan jumlah terbesar berasal dari Bantul dengan 12.434 lembar surat eligibilitas peserta (SEP), diikuti dengan Gunung Kidul dengan 4.322 lembar SEP, Kulon Progo dengan 3.401 lembar, Sleman dengan 3.300 lembar surat, sementara jumlah penerima Jamkesta terkecil berasal dari Kota Yogyakarta dengan jumlah klaim sebanyak 2.575 lembar SEP. Dari data tersebut, peneliti menyatakan bahwa masih banyak golongan masyarakat (diantaranya merupakan PMKS tanpa identitas dan bayi baru lahir) yang luput dari perhatian JKN, dan Jamkesta mampu memberikan solusi dengan membiayai biaya kesehatan mereka.

Pelaksanaan Jamkesta tidak hanya dikelola oleh Satuan Kerja Perangkat Daerah (SKPD) tingkat provinsi, tetapi juga bekerjasama dengan SKPD di tingkat Kabupaten/Kota serta pemerintah di tingkat Kecamatan. Bentuk kerjasama tersebut dapat dilihat dari laporan penemuan PMKS berupa gelandangan, pengemis, pemulung, dan anak jalanan kepada Dinas Sosial provinsi atau Dinas Sosial Kabupaten/Kota. Laporan yang dilakukan ke Dinas Sosial kabupaten/kota akan ditangani secara langsung Tenaga Kerja Sosial Kecamatan (TKSK). Selain kerjasama dari segi pelaporan, kerjasama juga terlihat dari segi pembagian porsi peneriman bantuan Jamkesta. Masyarakat yang tidak tercover oleh kebijakan JKN akan dibantu oleh Jaminan Kesehatan Daerah (Jamkesda) yang berada di tingkat Kabupaten/Kota. Namun masih ada golongan masyarakat tertentu (seperti PMKS tanpa KTP) yang tidak mendapatkan bantuan dari JKN maupun Jamkesda. Oleh itu, pemerintah Kabupaten/Kota akan merekomendasikan kepada Bapel Jamkesos, dan kemudian akan diverifikasi oleh Dinsos untuk mendapatkan bantuan pembiayaan kesehatan dari Pemerintah Daerah.

Peneliti menyimpulkan bahwa Jamkesta mampu membiayai biaya kesehatan untuk golongan-golongan yang luput dari perhatian Jaminan Kesehatan Nasional selama dia menetap di DIY. Selain itu, adanya kerjasama yang kuat antar kelompok teknis menunjukkan bahwa mereka sangat berkomitmen dalam meaksanakan visi dari sistem Jamkesta 
dan berusaha memenuhi amanat dari Gubernur DIY.

\section{Sosialisasi}

Sosialisasi kebijakan terbaru Jamkesta berupa Pergub Nomer 63 Tahun 2016 Tentang Jaminan Kesehatan Semesta dilakukan kepada tiga SKPD pelaksana kebijakan ini, yakni Bapel Jamkesos, Dinas Kesehatan DIY maupun Kabupaten/Kota, dan Dinas Sosial DIY dan Kabupaten/Kota. Selain itu, sosialisasi juga dilakukan dengan pihak eksternal berupa perwakilan dari Rumah Sakit, Pemberi pelayanan kesehatan (PPK), dan mitra yang bekerjasama dengan Bapel Jamkesos seperti Puskesmas dan BPJS. Proses sosialisasi kebijakan difasilitasi oleh Bapel Jamkesos dengan menggunakan biaya operasional.

Sosialisasi dilakukan melalui media seperti radio, koran, serta televisi, dan melalui pertemuan-pertemuan di kabupaten/kota yang biasanya melibatkan pemerintah di tingkat Kecamatan. Sosialisasi melalui media sosial seperti facebook dan twitter belum dilaksanakan, akan tetapi Bapel Jamkesos memiliki rencana untuk membuat web resmi Bapel Jamkesos dan facebook pada masa mendatang. Selain sosialisasi tentang Pergub Jamkesta, Bapel Jamkesos juga melakukan sosialisasi terkait hak dan kewajiban anggota. Sementara itu, berdasarkan observasi yang dilakukan di lapangan, sosialisasi kepada masyarakat umum mendapatkan repon positif. Hal ini terlihat dari banyaknya jumlah penuntut bantuan yang menghadiri kantor Bapel Jamkesos setiap harinya.

Respon positif dari masyarakat, dilihat dari jumlah SEP yang dikeluarkan oleh Bapel Jamkesos (seperti yang dijelaskan oleh peneliti dalam unsur lokasi) menunjukkan bahwa sosialisasi yang dilakukan oleh SKPD pelaksana sudah mencukupi. Selain itu, masyarakat memanfaatkan kebijakan dari pemerintah daerah dengan sebaik-baiknya.

\section{Respon terhadap Saran Perbaikan Inovasi}

Jika terdapat keluhan atau saran terkait kebijakan Jamkesta, masyarakat dapat menyampaikannya melalui email, telfon, faks, atau datang secara langsung ke kantor tim teknis, yakni Dinas Sosial, Dinas Kesehatan, atau Badan Pelaksana Jaminan Kesejahteraan Sosial. Masalah tersebut akan ditampung dan dilaporkan ke Biro Administrasi, yang kemudian biro tersebut akan memfasilitasi forum koordinasi untuk memecahkan permasalahan. Forum koordinasi dilaksanakan di Kompleks Kepatihan, yang mana anggotanya ditunjuk secara langsung oleh Gubernur DIY. 
Anggota dari forum tersebut adalah Dinas Pendapatan, Pengelolaan Keuangan dan Aset Daerah (DPPKA) yang berperan sebagai pengurus kas daerah, Biro Hukum yang berperan sebagai regulator kebijakan, Badan Pembangunan dan Perencanaan Daerah (BAPPEDA), Biro Organisasi yang memegang kendali dalam urusan

kelembagaan, Badan Kerjasama dan Permodalan, dan tim teknis (Dinas Sosial, Dinas Kesehatan, dan Badan Pelaksana Jaminan Kesejahteraan Sosial). SKPD-SKPD pelaksana Jamkesta sangat tanggap dalam menangani aspirasi dan keluhan dari masyarakat. Selain itu, sarana dan prasarana penyalur aspirasi dinilai sudah lengkap walaupun media berupa web resmi dan sosial media belum ada.

Sarana penyampaian saran atau keluhan sudah lengkap, namun alangkah baiknya jika setiap instansi dilengkapi dengan web resmi dan sosial media untuk memberikan kemudahan kepada masyarakat dan menarik minat lebih banyak golongan muda agar melibatkan diri dalam proses penyampaian pendapat.

\section{Unsur Eksternal Inovasi Pelayanan Publik}

1. Peraturan Perundang-undangan

Peraturan tentang sistem Jamkesta sudah dua kali mengalami proses revisi sejak dikeluarkannya Pergub Nomor 1 Tahun 2014 tentang Sistem Jaminan Kesehatan Semesta. Pada 24 September 2014, Pergub Nomer 73 tahun 2014 tentang perubahan atas Pergub Nomor 1 Tahun 2014 Tentang Sistem Jaminan Kesehatan Semesta mulai diimplementasikan. Dua tahun kemudian, yakni pada 29 Agustus 2016, Peraturan Gubernur Nomor 63 Tahun 2016 tentang Sistem Jaminan Kesehatan Semesta secara resmi dikeluarkan dan Pergub yang sebelumnya dinyatakan tidak berlaku lagi. Kebijakan ini mengalami revisi terus menerus karena adanya aspirasi, baik dari SKPD pelaksana, Monev ke lapangan, amanah UU Sistem Jaminan Sosial Nasional (SJSN), maupun dari masyarakat.

Proses revisi kebijakan dilakukan melalui rapat koordinasi antar aktor pelaksana Jamkesta. Untuk memastikan bahwa pelaksanaan kebijakan dapat berjalan lancar dan baik, maka di setiap SKPD pelaksana, yakni Dinas Sosial, Dinas Kesehatan, dan Badan Pelaksana Jaminan Kesejahteraan Sosial disediakan standar operasional Prosedur (SOP), yang 
mana setiap pegawai wajib mematuhi SOP tersebut selama menjalankan tugasnya. Sementara itu, monitoring kebijakan dilakukan melalui beberapa cara, yakni monitoring langsung ke lapangan yang umumnya diketuai oleh salah satu anggota dari BAPPEDA, dan rapat koordinasi dengan SKPD terkait.

Landasan hukum yang kuat dapat menjamin akurasi produk pelayanan publik, artinya, revisi kebijakan sistem Jamkesta yang dilakukan dengan tujuan untuk memastikan bahwa kebijakan senantiasa sesuai dengan keperluan masyarakat dari waktu ke waktu. Selain itu, landasan hukum dapat memberikan rasa aman kepada penerima layanan publik.

\section{Budaya}

Secara garis besar, masyarakat sebagai penerima layanan dari sistem Jamkesta sudah menjalankan perannya dengan baik, dengan cara memberi kerjasama dalam proses laporan temuan golongan PMKS kepada Dinas Sosial Provinsi atau Dinas Sosial Kabupaten/Kota. Hal ini mengindikasikan bahwa masyarakat sekitar memiliki rasa belas kasihan dan solidaritas yang tinggi terhadap orang lain, walaupun orang tersebut adalah orang asing dan sering dipandang sebagai sumber masalah sosial di kalangan masyarakat.
Akan tetapi, masih terdapat golongan masyarakat yang masih belum memiliki kepedulian untuk mengurus syarat-syarat administrasi dengan segera. Terkadang, ada antara wali pasien yang sudah dikabari bahwa surat sudah selesai melalui telefon, tetapi mereka beralasan untuk mengambilnya pada keesokan hari karna ada keperluan mendadak sehingga proses pengurusan akan menjadi lebih lama.

Tujuan akhir dari sebuah kebijakan adalah untuk melihat sejauh mana tingkat kepuasan penerima layanan, yang dalam konteks ini adalah masyarakat awam. Untuk mengukur kepuasan secara umum, pihak Bapel Jamkesos melakukan survei ringkas yang terdiri dari beberapa soalan. Survei yang dilakukan bersifat mandiri tanpa melibatkan pihak ketiga.

Dari survei yang dilakukan pada tahun 2016, diketahui bahwa kebanyakan masyarakat sudah puas dengan pelayanan yang diberikan karena timbal balik dari survei tersebut rata-rata menunjukkan reaksi yang positif, kotak saran sentiasa kosong, tidak ada keluhan dari masyarakat sewaktu di loket, dan juga tidak ada keluhan dari grup whatsapp dan email Bapel Jamkesos. 


\section{Pemanfaatan Teknologi}

Bapel Jamkesos belum memiliki web resmi ataupun akun media sosial seperti facebook maupun Twitter untuk mendukung aksesibilitas data dan penyampaian aspirasi dari masyarakat. Berbeda halnya dengan dua SKPD pelaksana lainnya. Dinas Kesehatan memiliki web resmi berupa Dinkes.jogjaprov.go.id, sementara Dinas Sosial juga memiliki web resmi berupa Dinsos.jogjaprov.go.id. Pada saat ini, Bapel Jamkesos sudah memiliki rencana untuk membuat web resmi Bapel Jamkesos dan juga Facebook resmi instansi tersebut, namun rencana tersebut belum dapat direalisasikan sehingga hujung tahun 2016.

Teknologi informasi merupakan sebuah keharusan bagi masyarakat modern. Oleh itu, alangkah baiknya apabila Bapel Jamkesos mampu membuat web resmi dan sosial media sesegera mungkin agar masyarakat dapat memanfaatkan teknologi informasi untuk mengakses pelayanan publik.

\section{Lingkungan Sosial}

Secara fisik, akses ke Dinas Sosial DIY, Dinas Kesehatan DIY, maupun Bapel Jamkesos DIY terbilang mudah dijangkau karena lokasi ketiga-tiga kantor SKPD ini berada berdekatan dengan pusat keramaian walaupun jarak lokasi antara satu kantor dan kantor lainnya terbilang jauh.

Lingkungan eksternal yang bersifat non-fisik dari sistem ini adalah rumah sakit dan puskesmas- puskesmas yang ada di sekitar DIY. Jangka waktu pencairan dana pembiayaan kesehatan kepada pasien tertentu tergantung kepada kecepatan pemberi layanan kesehatan dalam mengembalikan SEP beserta coding diagnosa penyakit. Jika pengajuannya cepat, maka jangka waktu pencairan dana menjadi cepat, dan begitu pula sebaliknya. Untuk menghindari keterlambatan pengajuan klaim, maka Bapel Jamkesos berinisiatif untuk melakukan sistem jemput bola ke puskesmas-puskesmas di daerah Gunung Kidul dan Kulon Progo. Sedangkan untuk wilayah Bantul, Sleman dan Kota Jogja, pihak puskesmas sendiri yang mengirimkan klaim ke Bapel Jamkesos.

Lingkungan sosial, baik yang bersifat fisik maupun non-fisik sudah mendukung pelaksanaan sistem Jamkesta bagi golongan penyangga dan bayi baru lahir. Diharapkan bahwa lingkungan sosial mampu mengoptimalkan pelaksanaan sistem Jamkesta melalui peningkatan angka kesejahteraan yang diukur dari taraf kesehatan. 


\section{SIMPULAN}

Berdasarkan analisis yang dilakukan terhadap pelaksanaan inovasi sistem Jaminan Kesehatan Semesta (Jamkesta) untuk golongan penyangga dan bayi baru lahir, peneliti menyimpulkan:

1. Unsur SDM, proses, pembiayaan, lokasi, respon terhadap saran perbaikan inovasi, hukum, dan sosial sudah mendukung pelaksanaan inovasi Jaminan Kesehatan Semesta terhadap golongan penyangga dan bayi baru lahir. Namun, masih terdapat beberapa kekurangan yang perlu diperbaiki jika dilihat dari unsur sosialisasi, budaya dan teknologi. Oleh karena itu, Bapel Jamkesos sebagai penggerak utama dalam sistem Jamkesta harus berusaha lebih giat agar pelaksanaan sistem ini menjadi optimal pada masa yang akan datang.

2. Unsur hasil menunjukkan bahwa sebanyak $45 \%$ dari total jumlah surat eligibilitas peserta (SEP) yang dikeluarkan oleh Bapel Jamkesos adalah untuk golongan penyangga tanpa KTP dan bayi baru lahir. Hal tersebut mengindikasikan bahwa Jamkesta benar- benar mampu meningkatkan kualitas pelayanan kesehatan golongan penyangga dan bayi baru lahir karena visi utama sistem Jamkestadan amanah dari Gubernur DIY sudah tercapai.

Guna memperbaiki pelaksanaan inovasi Jaminan Kesehatan Semesta di Daerah Istimewa Yogyakarta, peneliti memberikan beberapa saran, antaranya:

1. Bapel Jamkesos perlu menyegerakan pembuatan web resmi dan media sosial, seperti facebook dan twitter agar proses sosialisasi dan sarana penerima aspirasi serta keluhan dapat diperbaiki. Selain itu, sosialisasi juga perlu dilakukan dengan cara lebih banyak mendekati masyarakat secara langsung untuk mengubah cara fikir mereka terhadap prosedur pelayanan sistem Jamkesta.

2. Perlu dibuat satu aplikasi khusus untuk membantu pengajuan klaim daru rumah sakit atau puskesmas kepada Bapel Jamkesos, sehingga pegawai Bapel Jamkesos tidak perlu lagi melaksanakan sistem jemput bola, dan pegawai-pegawai yang ada di rumah sakit atau puskesmas tidak perlu menghantar langsung klaim ke kantor Bapel Jamkesos. 


\section{DAFTAR PUSTAKA}

$\begin{array}{cc}\text { Dinas Sosial DIY. Laporan } & \text { Hasil } \\ \text { Pemutakhiran Data } & \text { PMKS } \\ \text { dan PSKS } & \text { Tahun } \\ \text { 2014.Yogyakarta } & \end{array}$

Kementerian Kesehatan RI. 2015. Profil Kesehatan Indonesia Tahun 2014. Jakarta: Kementerian Kesehatan RI.

Sugiyono. 2011. Metode Penelitian Kualitatif, Kuantitatif dan $R \& D$. Bandung: Alfabeta

Muhammad Imanuddin. 2015. Inovasi Pelayanan Publik di Indonesia. Disertasi, tidak dipublikasikan. Universitas Diponegono

Peraturan Gubernur Daerah Istimewa Yogyakarta Nomor 63 Tahun 2016 Tentang Sistem Jaminan Kesehatan Semesta.

Peraturan Menteri Kesehatan Nomer 52 Tahun 2016 Tentang Standar Tarif Pelayanan Kesehatan Dalam Penyelenggaraan Program Jaminan Kesehatan. 